\title{
ASSESSMENT OF EQUIPMENT EFFICIENCY IN MODELS OF TECHNOLOGICAL PROCESSES FOR PRODUCTION OF COMBINED FEED
}

\author{
Marina Chkalova, Victoria Pavlidis \\ Orenburg State Agrarian University, Russia \\ chkalovamv@mail.ru,pavlidis@mail.ru
}

\begin{abstract}
Structural and functional models of technological processes that implement the basic layout schemes of industrial equipment for the combined feed production were used in the research. The mathematical apparatus of vector analysis, factor analysis, and cluster analysis became the basis of algorithms for determining the set of factors that affect the production line efficiency. As a result of the research, a methodology for evaluating the efficiency of technological equipment of an industrial line for the combined feed production was developed and justified. On the example of studying the technological equipment for mixing mixed feeds, the invariant parameters and design features of mixers that improve the basic optimization indicators (equipment reliability, quality of the finished product and specific energy consumption) were determined. The article forms a system of relative efficiency indicators of various types of mixers in the industrial process line, develops calculation formulas for determining the relative efficiency indicators of equipment, and calculates the group coefficient of factor efficiency. The authors developed and implemented a method for calculating the synergetic efficiency coefficient of an industrial technological line for the production of combined feed, taking into account both the choice of the method of production organization and the optimal choice of the type of technological equipment. The results obtained led to the creation of a universal methodology for evaluating the effectiveness of industrial and technological lines for combined feed production, which was tested in real industrial production in the Russian Federation and, in particular, in the Orenburg region and proved its usefulness.
\end{abstract}

Keywords: feed production, mixers, evaluation methodology, performance indicators.

\section{Introduction}

The main directions of the feed production development are to increase the volume of products produced while reducing the level of production costs and improving the quality of the feed produced. The identified areas are related to the technological equipment modernization, the adaptation of production line management systems to the conditions of digitalization of modern agricultural production and the raw material base expansion [1].

A deep analysis of the industry complex problems and a systematic approach to the technological processes study allowed to form the concept of three effects of feed production development [2].

Digital automated process control systems of a modern feed mill are configured for a specific equipment type, which makes it very difficult to regularly upgrade it. The first development effect arises from the organization of production itself on the basis of basic principles optimal combination. The second development effect arises and enhances the first one on the basis of the correct choice of types of technological equipment and its location structural schemes, which leads to the alignment of feed flows and, consequently, the output product granulometric composition improvement. The third development effect occurs when the components in the raw materials are replaced by innovative components in an ultrafine (nano) form.

Earlier, the authors analyzed the effectiveness of methods for organizing the combined feed production [3]. In this work, the main focus is on the first effect implementing possibilities.

The prospects for using the potential of the second effect were the subject of study in this research. The hypothesis of the synergistic interaction of the first two effects formed the basis of the concept of this work. Based on the proven effectiveness of the two most promising methods of organizing the technological process of combined feed production (the formation of preliminary mixtures without repeated dosing and the direct-flow method) [3], we will study the possibilities of solving the problem of optimizing technological equipment using the example of feed component mixers.

The development of technology and the development of equipment for industrial feed production were dealt with by Russian scientists: N.E. Avdeev, V.V. Gortinsky, V.M. Tsetsinovsky, A.Yu. Shazzo et al., Scientists from Buhler A., Hansen R., Mogensen F. et al [4-8].

Thus, our research purpose is to analyze the engineering and technological parameters of machines and equipment used for mixing feed, and to build an optimization model for the process. To achieve this goal, we have solved the following tasks: we have analyzed the technical and technological parameters

DOI: 10.22616/ERDev.2021.20.TF193 
of the mixers; we have determined the operating conditions of the feed mixing equipment; we have built an optimization model for the equipment choice.

\section{Materials and methods}

According to the working bodies design, industrial mixers for the mixed feed production are classified as vane, belt, screw, drum and turbine [4-8]. Based on the study of the technological equipment for mixing mixed feeds, we determined the invariant parameters and design features of the mixers that improve the basic optimization indicators (reliability, finished product quality and specific energy consumption).

In the course of the study, we identified design features that simultaneously affect the reliability degree, the finished product quality, and the energy consumption level (Table. 1), which can be used for further technological equipment modernization.

Table 1

Analysis of technological parameters

\begin{tabular}{|c|c|c|}
\hline $\begin{array}{c}\text { Types } \\
\text { of mixers }\end{array}$ & $\begin{array}{c}\text { Main } \\
\text { working body }\end{array}$ & Invariant parameters and design features \\
\hline \multirow{2}{*}{$\begin{array}{l}\text { Vane mixers } \\
\text { (I) }\end{array}$} & \multirow[t]{2}{*}{ Blade } & $\begin{array}{l}\text { mixing time (40-150 s); shaft speed (20-35 rpm); mixture } \\
\text { uniformity coefficient }(96-98 \%) \text {; }\end{array}$ \\
\hline & & blades rotation angle relative to the shaft \\
\hline \multirow{2}{*}{$\begin{array}{l}\text { Belt mixers } \\
\text { (II) }\end{array}$} & \multirow[t]{2}{*}{ Belt } & $\begin{array}{l}\text { mixing time }(300-420 \mathrm{~s}) \text {; shaft speed }(28-35 \mathrm{rpm}) \text {; mixture } \\
\text { uniformity coefficient }(93-96 \%)\end{array}$ \\
\hline & & tape step by working chamber \\
\hline \multirow{2}{*}{$\begin{array}{l}\text { Screw } \\
\text { mixers } \\
\text { (III) }\end{array}$} & \multirow[t]{2}{*}{ Auger } & $\begin{array}{l}\text { mixing time }(900-1200 \mathrm{~s}) \text {; shaft speed }(5-400 \mathrm{rpm}) \text {; mixture } \\
\text { uniformity coefficient }(85-92 \%) \text {; }\end{array}$ \\
\hline & & screw turns number \\
\hline \multirow{2}{*}{$\begin{array}{l}\text { Drum mixers } \\
\text { (IV) }\end{array}$} & \multirow{2}{*}{ Drum } & $\begin{array}{l}\text { mixing time }(90-240 \mathrm{~s}) \text {; shaft speed }(28-35 \mathrm{rpm}) \text {; mixture } \\
\text { uniformity coefficient }(85-90 \%) \text {; }\end{array}$ \\
\hline & & angle of inclination of the axis of rotation of the drum \\
\hline \multirow{2}{*}{$\begin{array}{l}\text { Turbine } \\
\text { mixers } \\
\text { (V) }\end{array}$} & \multirow{2}{*}{$\begin{array}{l}\text { Shaft with } \\
\text { blades }\end{array}$} & $\begin{array}{l}\text { mixing time }(60-240 \text { s); shaft speed }(-) \\
\text { mixture uniformity coefficient }(85-90 \%)\end{array}$ \\
\hline & & blades rotation angle relative to the shaft \\
\hline
\end{tabular}

Thus, the optimization of the mixing feed equipment selection must be carried out according to the invariant parameters system. The results of the comparative analysis of the invariant parameters values intervals for the types of mixers led to the possibility of specifying the scalar field vector function.

The first two parameters (mixing time and shaft speed) should be optimized to a minimum. As a field, we take the set of points of the plane with coordinates $(v, t)$, where $v$-is the number of revolutions of the shaft (rpm), $t$-is the mixing time (s). The optimization criterion in this case will be the modulus of the vector function value (the length of the corresponding radius vector) (Fig. 1): $|\vec{r}(v, t)|$.

We will calculate the criterion according to the data from Table 1 and give a geometric interpretation in Figure 1:

$$
\begin{gathered}
|\vec{r}(150,35)|=\sqrt{150^{2}+35^{2}} \approx 154 \\
|\vec{r}(420,35)|=\sqrt{420^{2}+35^{2}} \approx 421 \\
|\vec{r}(1200,400)|=\sqrt{1200^{2}+400^{2}} \approx 1265 \\
|\vec{r}(240,35)|=\sqrt{240^{2}+35^{2}} \approx 243 \\
|\vec{r}(240,0)|=\sqrt{240^{2}+0^{2}} \approx 240
\end{gathered}
$$


The optimum mixing time and the number of shaft revolutions are given by vane mixers. The following result on the optimality of these criteria is shown by turbine mixers. The third parameter (the mixture homogeneity coefficient) is optimized to the maximum, and according to this criterion, the best result is also for paddle mixers.

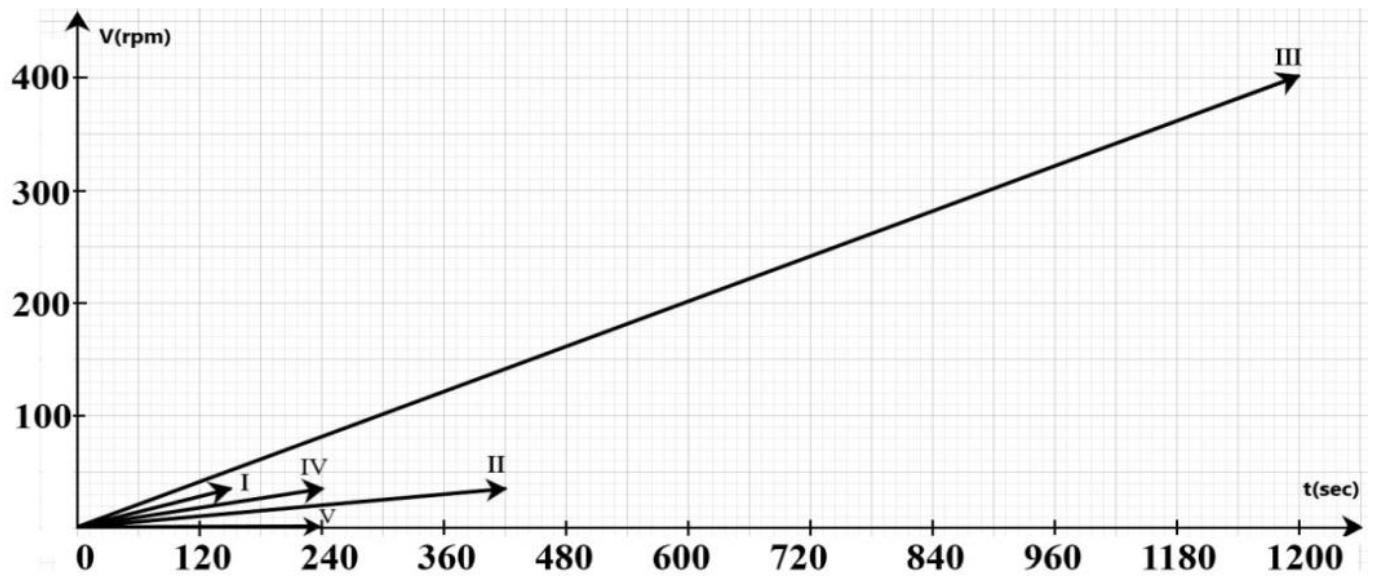

Fig. 1. Vector function values of the parameter field $(v, t)$

The method proposed by the authors for constructing an optimization model for the selection of technological equipment includes the analysis of technical and technological parameters, the invariants determination, the equipment operating conditions selection and the optimality criterion calculation. It is universal and can be used in any field of production activity.

The scientific and technical sources analysis [5-8] allowed the authors to classify the factors that both contribute to improving the efficiency of the mixing process and reduce it (Table 2).

Table 2

\section{Efficiency factors of different mixer types}

\begin{tabular}{|c|c|c|}
\hline Mixer type & Factor + & $\begin{array}{l}\text { Factor - } \\
\end{array}$ \\
\hline $\begin{array}{l}\text { Vane mixers } \\
\text { (I) }\end{array}$ & $\begin{array}{l}\text { - high mixing uniformity (96-98\%); } \\
\text { - fast mixing ( } 40-150 \text { s); } \\
\text { - permissible loading rate of } 15-20 \% \\
\text { of the volume (for small batches); } \\
\text { - possibility of introducing up to } 7 \% \\
\text { of liquid components; } \\
\text { - almost complete emptying of the } \\
\text { working chamber }\end{array}$ & $\begin{array}{l}\text { - relatively expensive compared to other } \\
\text { types; } \\
\text { - conditionally aggressive to feed materials; } \\
\text { - possibility of damage to the feed product } \\
\text { due to high rotation speed }\end{array}$ \\
\hline $\begin{array}{l}\text { Belt mixer } \\
\text { (with } \\
\text { horizontal } \\
\text { shaft) (II) }\end{array}$ & $\begin{array}{l}\text { - high mixing uniformity }(95-96 \%) \text {; } \\
\text { - mixing without significant damage } \\
\text { to the components; } \\
\text { - the possibility of introducing liquid } \\
\text { components up to } 5 \% \text { of the volume }\end{array}$ & $\begin{array}{l}\text { - risk of incomplete emptying of the working } \\
\text { chamber and contamination of the following } \\
\text { recipes; } \\
\text { - satisfactory mixing time and good quality } \\
\text { only when filling more than half the volume }\end{array}$ \\
\hline $\begin{array}{l}\text { Screw } \\
\text { mixers } \\
\text { (with } \\
\text { vertical } \\
\text { agitator) } \\
\text { (III) }\end{array}$ & $\begin{array}{l}\text { - lower cost compared to other types; } \\
\text { - easy assembly as part of industrial } \\
\text { lines; } \\
\text { - reduction of time costs in industrial } \\
\text { production; } \\
\text { - ability to reduce power; } \\
\text { - mixing without significant damage } \\
\text { to the components; }\end{array}$ & $\begin{array}{l}\text { - long-term mixing and unloading of the } \\
\text { mixture; } \\
\text { - low mixing uniformity (no more than } \\
92 \% \text { ); } \\
\text { - risk of incomplete emptying of the working } \\
\text { chamber; } \\
\text { - inability to mix more than } 3 \% \text { of liquid } \\
\text { components; } \\
\text { - more energy-intensive compared to other } \\
\text { types; } \\
\text { - rapid wear of screw turns; } \\
\text { - complex repairs }\end{array}$ \\
\hline
\end{tabular}


Table 2 (continued)

\begin{tabular}{|c|c|c|}
\hline Mixer type & Factor + & Factor - \\
\hline $\begin{array}{c}\text { Drum mixers } \\
\text { (IV) }\end{array}$ & $\begin{array}{l}\text { - reduction of time costs in industrial } \\
\text { production; } \\
\text { - mixing without significant damage to } \\
\text { feed components; } \\
\text { - wide scope of application; } \\
\text { - possibility of using a large volume of } \\
\text { raw materials }\end{array}$ & $\begin{array}{l}\text { - failure to provide a consistent } \\
\text { uniformity level; } \\
\text { - control complexity when } \\
\text { changing operating modes; } \\
\text { - variable particle size } \\
\text { distribution; } \\
\text { - mixing components } \\
\text { segregation }\end{array}$ \\
\hline Turbine mixers $(\mathrm{V})$ & $\begin{array}{l}\text { - possibility of introducing liquid } \\
\text { components up to } 10 \% \text { of the volume; } \\
\text { - possibility of simultaneous } \\
\text { administration of up to } 3 \text { types of liquid } \\
\text { components; } \\
\text { - compact design, easy maintenance and } \\
\text { reliable operation }\end{array}$ & $\begin{array}{l}\text { - satisfactory uniformity of the } \\
\text { feed mixture with liquid } \\
\text { components of different } \\
\text { viscosities }\end{array}$ \\
\hline
\end{tabular}

\section{Results and discussion}

The authors introduced a relative indicator of the efficiency of the types of mixers: the factor efficiency coefficient, calculated as the ratio of the number of positive factors Ind(+) to the total number of factors

$$
S=\operatorname{Ind}(+)+\operatorname{Ind}(-): K_{f e}=\operatorname{Ind}(+) / S .
$$

Calculations for each type of mixer show the following:

- $\quad$ vane mixers $-\operatorname{Ind}(+)=5, \operatorname{Ind}(-)=3, S=8, K_{f e}=5 / 8=0.62$;

- belt (with horizontal shaft) mixers $-\operatorname{Ind}(+)=3, \operatorname{Ind}(-)=2, S=5, K_{f e}=3 / 5=0.6$;

- screw (with vertical agitator) mixers $-\operatorname{Ind}(+)=5, \operatorname{Ind}(-)=7, S=12, K_{f e}=5 / 12=0.42$;

- drum mixers $-\operatorname{Ind}(+)=4, \operatorname{Ind}(-)=4, S=8, K_{f e}=4 / 8=0.5$;

- turbine mixers $-\operatorname{Ind}(+)=3, \operatorname{Ind}(-)=1, S=4, K_{f e}=3 / 4=0.75$.

The factor efficiency coefficient can be interpreted as the mixer's efficiency. According to this indicator, turbine and vane mixers are distinguished.

We will cluster a set of factors, dividing the factors that affect the mixer efficiency into three groups: factors that affect energy consumption, product quality, and operational properties (Table 3).

\section{Clustering of mixer efficiency factors}

\begin{tabular}{|c|c|c|c|}
\hline Factor & Energy consumption & Product quality & Operational properties \\
\hline Factor + & $\begin{array}{l}\text { - fast mixing; } \\
\text { - ability to reduce } \\
\text { power; } \\
\text { - reduction of time costs } \\
\text { in industrial production }\end{array}$ & $\begin{array}{l}\cdot \text { - high mixing } \\
\text { uniformity; } \\
\text { - mixing without } \\
\text { significant } \\
\text { damage to the } \\
\text { components }\end{array}$ & $\begin{array}{l}\text { - permissible loading rate of } 15-20 \% \\
\text { of the volume (for small batches); } \\
\text { - possibility of introducing up to } 5- \\
10 \% \text { of liquid components; } \\
\text { - almost complete emptying of the } \\
\text { working chamber; } \\
\text { - lower cost compared to other types; } \\
\text { - easy assembly as part of industrial } \\
\text { lines; } \\
\text { - wide scope of application; } \\
\text { - possibility of using a large volume of } \\
\text { raw materials; } \\
\text { - compact design, easy maintenance } \\
\text { and reliable operation }\end{array}$ \\
\hline
\end{tabular}


Table 3 (continued)

\begin{tabular}{|c|c|c|c|}
\hline Factor & Energy consumption & Product quality & Operational properties \\
\hline Factor - & $\begin{array}{l}\text { - long-term mixing and } \\
\text { unloading of the } \\
\text { mixture; } \\
\text { - more energy-intensive } \\
\text { compared to other types }\end{array}$ & $\begin{array}{l}\text { - risk of the feed product } \\
\text { damage due to high } \\
\text { rotation speed; } \\
\text { - satisfactory mixing time } \\
\text { and good quality only } \\
\text { when filling more than } \\
\text { half of the volume; } \\
\text { - low mixing uniformity } \\
\text { (no more than 92\%); } \\
\text { - failure to provide a } \\
\text { consistent uniformity } \\
\text { level; } \\
\text { - variable particle size } \\
\text { distribution; } \\
\text { - segregation of mixing } \\
\text { components }\end{array}$ & $\begin{array}{l}\text { - relatively expensive } \\
\text { compared to other types; } \\
\text { - conditionally aggressive to } \\
\text { feed materials; } \\
\text { - risk of incomplete emptying } \\
\text { of the working chamber and } \\
\text { contamination of the following } \\
\text { recipes; } \\
\text { - inability to mix more than } 3 \% \\
\text { of liquid components; } \\
\text { - complex repairs; } \\
\text { - complexity of control when } \\
\text { changing operating modes }\end{array}$ \\
\hline
\end{tabular}

Based on the data obtained, the authors calculated the group factor efficiency coefficient as the ratio of the number of positive factors to the total number of factors for each selected class (Table 4).

Group coefficient of factor efficiency of mixers

Table 4

\begin{tabular}{|c|c|c|c|c|c|}
\hline \multirow{2}{*}{ Factor } & \multicolumn{5}{|c|}{ Mixer type } \\
\cline { 2 - 6 } & Vane mixers & Belt mixers & $\begin{array}{c}\text { Screw } \\
\text { mixers }\end{array}$ & $\begin{array}{c}\text { Drum type } \\
\text { mixers }\end{array}$ & $\begin{array}{c}\text { Turbine } \\
\text { mixers }\end{array}$ \\
\hline \multirow{2}{*}{$\begin{array}{c}\text { Energy } \\
\text { consumption }\end{array}$} & $\operatorname{Ind}(+)=1$ & $\operatorname{Ind}(+)=0$ & $\operatorname{Ind}(+)=2$ & $\operatorname{Ind}(+)=1$ & $\operatorname{Ind}(+)=0$ \\
\cline { 2 - 6 } & $S=5$ & $S=5$ & $S=5$ & $S=5$ & $S=5$ \\
\cline { 2 - 6 } & $K_{e c}=0.2$ & $K_{e c}=0$ & $K_{e c}=0.4$ & $K_{e c}=0.2$ & $K_{e c}=0$ \\
\hline \multirow{2}{*}{$\begin{array}{c}\text { Product } \\
\text { quality }\end{array}$} & $\operatorname{Ind}(+)=1$ & $\operatorname{Ind}(+)=2$ & $\operatorname{Ind}(+)=1$ & $\operatorname{Ind}(+)=1$ & $\operatorname{Ind}(+)=0$ \\
\cline { 2 - 6 } & $S=8$ & $S=8$ & $S=8$ & $S=8$ & $S=8$ \\
\cline { 2 - 6 } $\begin{array}{c}\text { Operational } \\
\text { properties }\end{array}$ & $K_{q}=0.125$ & $K_{q}=0.25$ & $K_{q}=0.125$ & $K_{q}=0.125$ & $K_{q}=0$ \\
\cline { 2 - 6 } & $\operatorname{Ind}(+)=3$ & $\operatorname{Ind}(+)=1$ & $\operatorname{Ind}(+)=2$ & $\operatorname{Ind}(+)=2$ & $\operatorname{Ind}(+)=2$ \\
\cline { 2 - 7 } & $K_{o p}=0.21$ & $K_{o p}=0.07$ & $K_{o p}=0.14$ & $K_{o p}=0.14$ & $K_{o p}=0.14$ \\
\hline
\end{tabular}

The group efficiency coefficient calculation makes it possible to distinguish the best types of mixers for each factor: screw mixers are the least energy-consuming, horizontal mixers give the highest quality of the output product and vane mixers have the best operational properties.

Let us consider the application of the authors' methods for calculating the production organization efficiency [9] and the technological equipment choice on the example of functioning feed mills. The top three manufacturers of feed mill equipment in the Russian Federation (ranking by volume of production and demand for equipment) include the engineering company "Technex"(Voronezh) [10], OAO" VNIIKP" (Voronezh) [11], AST Region (Arzamas) [12].

The two most promising methods of organizing the technological process of combined feed production: the preliminary mixture formation without repeated dosing and the direct-flow method are implemented in the basic configuration of the industrial lines of the first two manufacturers. For mixing feed components Technex lines can be equipped with paddle and screw mixers, VNIIKP uses paddle mixers in industrial lines. Technex production provides customers with the ability to combine the spatial arrangement of equipment, VNIIKP equipment can only be installed vertically.

We calculate the synergistic efficiency $K_{\text {synef }}$ of industrial lines for the animal feed production, taking into account the choice of the method of production organization $K_{e f}$, and the technological equipment choice $K_{f e}$ (in our case, mixer):

$$
K_{\text {synef }}=K_{e f} K_{f e}+K_{l g},
$$


where $K_{l g}=K_{e f} \cdot K_{e}-$ coefficient factor of the effectiveness of the link gain (when using the optional equipment of the same kind).

Technex:

$$
K_{\text {synef }}=K_{e f} \cdot K_{f e}+K_{l g}=0.75 \cdot 0.62+0.75 \cdot 0.25=0.6525 ;
$$

"VNIIKP":

$$
K_{\text {synef }}=K_{\text {ef }} \cdot K_{f e}+K_{l g}=0.75 \cdot 0.62+0=0.465 .
$$

Therefore, the industrial line that implements the most effective ways of organizing the technological process of combined feed production: the formation of preliminary mixtures without repeated dosing and the direct-flow method and includes the optimal equipment in the complete set, has a higher efficiency.

\section{Conclusions}

Thus, the authors have identified a system of factors that affect the efficiency of mixers of various types, carried out their classification; developed methods for calculating the relative efficiency indicators of mixers; calculating the group coefficient of factor efficiency; proved (based on the concept of three effects of the development of feed production) the synergistic effect of the simultaneous application of the optimal method of organizing production and the choice of technological equipment.

Methods for determining the synergetic efficiency of feed production based on the calculation of the entered coefficients were tested at the leading enterprise of the feed industry, OAO "Orenburg Feed Mill" and proved their practical significance [13].

The developed methods are universal and can be used to optimize various types of technological equipment for agricultural production. Verification of the constructed models and the developed methodology implementation allows to consider the results obtained as reliable and applicable in the organization of technological processes in the feed industry.

\section{References}

[1] "Agriculture development and regulation of markets for agricultural products, raw materials and foodstuffs in the Orenburg region" for 2013-2020 // Decree of the Government of the Orenburg region. 2012.-№ 751 from 31.08.2012.

[2] Chkalova M., Shakhov V. The concept of innovative development of combined feed industrial production. -Equipment and technologies in animal breeding 2020, No. 2 (38). pp. 44-54

[3] Chkalova M., Shakhov V., Pavlidis V. Analysis of the effectiveness of methods of organizing the production of mixed feeds - In the collection: Rural Development Engineering 2019. pp. 462-468

[4] Miand A. E. Forage preparation machines and aggregates.- Moscow, Mashinostroenie, 1970.

[5] Kolobov M. Yu., Lapshin V.B., Sakharov S.E. Forage mixer .- Agricultural machinery, 2008.- No. 6.- pp. 46-48

[6] Zaitsev S.P., Zaitseva N.P. Economic and energy efficiency of feed preparation technology.Mechanization and electrification of agriculture, 2007.- No. 11.- pp. 16-18

[7] Konovalov V. V. et al. Mechanization of technological processes of animal breeding (monograph)/Penza, RIO PGSHA, 2006. 119 p.

[8] Loskutov A. Equipment for the mixed feed production.- Kombikorma, 2001. - No. 4. - p. 23

[9] Burlutsky E. M., Pavlidis V.D., Chkalova M.V. Mathematical modeling of technology and technical means for grinding feed raw materials (monograph)/Publishing House of the Orenburg State Agrarian University, 2010.-177 p.

[10] "Technex" Machine-building company [online] [19.03.2021] Available at: http://technex.ru

[11] OAO "VNIIKP" [online] [19.03.2021] Available at: http:// vniikp.ru

[12] AST Region [online] [19.03.2021] Available at: http://ast-region.ru

[13] OAO “Orenburg feed mill” [online] [19.03.2021] Available at: http://orenkz.ru 